Note

\title{
Inhibitory Effects of Bovine Lactoferrin and Lactoferricin B on Enterobacter sakazakii
}

\author{
HIROYUKI WAKABAYASHI ${ }^{1 *}$, KOJI YAMAUCHI ${ }^{1}$, AND MITSUNORI TAKASE ${ }^{2}$ \\ ${ }^{1}$ Food Science \& Technology Institute and ${ }^{2}$ Nutritional Science Institute, \\ Morinaga Milk Industry Co., Ltd., Zama, Kanagawa 228-8583, Japan
}

Received 18 September, 2007/Accepted 17 November, 2007

\begin{abstract}
The susceptibility of Enterobacter sakazakii, a food-borne pathogen, to several metal-bound forms of bovine lactoferrin (LF), pepsin-hydrolyzed LF (LF-hyd), and LF-derived peptide lactoferricin B (LFcin B) was tested. MIC and MBC testing revealed that 4 strains of $E$. sakazakii show susceptibility to apo- and Cu-LF, LF-hyd, and LFcin B, but not to Fe-LF, similarly to Escherichia coli. A growth curve test indicated that $E$. sakazakii was inhibited in a dose-dependent manner by apo-LF at 0.5 to $8 \mathrm{mg} / \mathrm{ml}$. Even after being heated at $80^{\circ} \mathrm{C}$, $\mathrm{LF}$ at above $1 \mathrm{mg} / \mathrm{ml}$ inhibited the bacterial growth. These results suggest that bovine LF-related compounds may be useful for the inhibition of $E$. sakazakii in foods.
\end{abstract}

Key words : Enterobacter sakazakii/Lactoferrin/Lactoferricin/Antimicrobial activity/Infant formula.

Enterobacter sakazakii is a bacterium belonging to the family Enterobacteriaceae. E. sakazakii is an opportunistic pathogen implicated in outbreaks of meningitis characterized by brain abcesses, and of enteritis such as necrotizing enterocolitis, especially in neonates and infants, occurring at a low frequency of disease but sometimes causing death (Lehner and Stephan, 2004). Foods, especially infant formula, have been suspected of being sources of infection (Drudy et al., 2006; Kandhai et al., 2004; Van Acker, et al., 2001). Recently, the Food and Agriculture Organization of the United Nations (FAO) and World Health Organization (WHO) (2007) issued "Safe preparation, storage and handling of powdered infant formula - Guidelines" to minimize the risk of $E$. sakazakii infection. It is recommended that powdered infant formula be prepared with water at a temperature of no less than $70^{\circ} \mathrm{C}$, which markedly reduces the risk. The antimicrobial activity of food components against this bacterium has been reported only for a medium-chain monoacylglycerol, monocaprylin (Nair et al., 2004), and milk casein-derived antimicrobial peptides (Hayes et al., 2006).

Lactoferrin (LF) is a metal-binding innate-defense

*Corresponding author. Tel: +81-46-252-3045, Fax : +8146-252-3059. protein and a component of milk, other exocrine secretions, and neutrophils. Bovine LF is used as a supplement in several foods such as infant formula (Wakabayashi et al., 2006). LF shows antimicrobial activity against various pathogenic bacteria in vitro via iron-deprivation and other mechanisms, and via oral administration (Chierici, 2001; Wakabayashi et al., 2006). For example, oral administration of LF suppresses the overgrowth and translocation of Enterobacteriaceae in the intestine of milk-fed mice (Teraguchi et al., 1995). LF also releases the antimicrobial peptide lactoferricin (LFcin) upon pepsin digestion (Bellamy et al., 1992; Wakabayashi et al., 2003). In this study, we investigated the susceptibility of E. sakazakii in comparison with Escherichia coli, a member of Enterobacteriaceae, to LF-related compounds such as several metal-bound forms of bovine LF and bovine LF-derived peptide LFcin B.

Bovine LF was produced by Morinaga Milk Industry (Tokyo, Japan). Apo-LF was prepared by the depletion of iron through the incubation of native bovine LF in $0.1 \mathrm{M}$ citric acid solution and dialysis against distilled water. Fe- and Cu-bound LF were prepared from apo-LF according to the previously reported method (Ainscough et al., 1979). Binding of $\mathrm{Fe}$ and $\mathrm{Cu}$ to the metal-chelating site of LF was confirmed by measuring the absorbance $\max$ at 465 and $438 \mathrm{~nm}$, 
respectively (Ainscough et al., 1979). The metal content of these preparations was measured by atomic absorption spectrometry. The metal saturation rate was $8.1 \% \mathrm{Fe}$ for native LF, 3.5\% Fe for apo-LF, 83.6\% Fe for Fe-LF, and $82.5 \%$ Cu for Cu-LF, respectively. LF hydrolyzate (LF-hyd) was produced by the pepsin hydrolyzation of bovine LF (Bellamy et al., 1992), and LFcin B was purified from LF-hyd as previously described (Tomita et al., 2002).

The $E$. coli strains used in this study were 0111 and IID861. E. sakazakii strains ATCC12868, ATCC29004, ATCC29544 ${ }^{\top}$, and ATCC51329 were purchased from the American Type Culture Collection (Nanassas, VA, USA). E. coli and E. sakazakii were grown and maintained on Tripticase Soy agar (BD, Franklin Lakes, NJ, USA), and incubated in 1\% Bactopeptone broth (BD) for the preparation of inocula.

For the determination of the minimum inhibitory concentration (MIC), the micro-broth dilution method was carried out. About $10^{6}$ bacteria/ml were incubated in $200 \mu$ l of $1 \%$ Bactopeptone broth at $37^{\circ} \mathrm{C}$ for $17 \mathrm{~h}$ in the presence of 2-fold serial dilutions of the test agents. MIC was defined as the lowest concentration of a given agent that resulted in no visible bacterial growth as tested in triplicate. After MIC testing, $2 \mu \mathrm{l}$ of the culture was incubated on a Tripticase Soy agar plate at $37^{\circ} \mathrm{C}$ for $5 \mathrm{~h}$. Then the minimum bactericidal concentration (MBC) was defined as the lowest concentration of a given agent that resulted in no colony formation as tested in triplicate. For the determination of the growth curve, about $10^{4}$ colony forming unit $(\mathrm{CFU}) / \mathrm{ml}$ were incubated in $1 \%$ Bactopeptone broth at $37^{\circ} \mathrm{C}$ for $5 \mathrm{~h}$ in the presence of apo-LF. Bacterial growth was determined by ATP-based luminescence quantification using a BacTiter-Glo Microbial Cell Viability Assay (Promega, Madison, WI, USA) and a Veritas Microplate Luminometer (Promega). Growth was expressed in relative lumi- nescence units (RLUS). To determine the heat resistance of LF, native LF was dissolved in water at 80 ${ }^{\circ} \mathrm{C}$ and cooled to room temperature. Then, the heattreated or non-treated LF was incubated with about $10^{6} \mathrm{CFU} / \mathrm{ml}$ of E. sakazakii ATCC51329 in $200 \mu \mathrm{l}$ of $1 \%$ Bactopeptone broth at $37^{\circ} \mathrm{C}$ for $17 \mathrm{~h}$. Serial dilutions of the culture were incubated on the agar plate at $37^{\circ} \mathrm{C}$ for $17 \mathrm{~h}$, and values of CFUs were determined.

MIC testing revealed that all strains of E. sakazakii show susceptibility to LF-hyd and LFcin B in a straindependent manner (Table 1). LF-hyd and LFcin B showed slightly higher MIC against $E$. sakazakii $(0.25-1 \mathrm{mg} / \mathrm{ml}$ and $0.016-0.031 \mathrm{mg} / \mathrm{ml}$, respectively) than against $E$. coli $(0.13-0.25 \mathrm{mg} / \mathrm{ml}$ and $0.08-0.016$ $\mathrm{mg} / \mathrm{ml}$, respectively). The MIC of apo-LF and metalbound LF was not determined, because these compounds caused turbidity in the medium even without bacterial inoculation. Instead, all compounds were assessed by MBC testing. Apo-LF, Cu-LF, LF-hyd, and LFcin $B$ had strain-dependent $M B C$ values against $E$. sakazakii (Table 1). These compounds showed slightly higher $\mathrm{MBC}$ against $E$. sakazakii than against E. coli. Cu-LF exhibited MBC values almost two times lower $(0.5-4 \mathrm{mg} / \mathrm{ml})$ than those of apo-LF $(1-8 \mathrm{mg} /$ $\mathrm{ml}$ ) against $E$. sakazakii and $E$. coli. Fe-LF up to 8 $\mathrm{mg} / \mathrm{ml}$ was not effective in this test, except against $E$. coli IID861 and E. sakazakii ATCC51329. The MBC values of LFcin $B$ were the same as the MIC values against all tested strains, suggesting that this compound acts in a bactericidal rather than bacteriostatic manner.

The effect of apo-LF on the growth curves of E. coli and E. sakazakii was investigated using an ATPbased luminescence quantification method (Fig. 1). E. coli and E. sakazakii grew logarithmically during 5 $h$ of incubation without a test compound. Apo-LF at $0.5 \mathrm{mg} / \mathrm{ml}$ showed a weak growth-inhibitory effect against all strains of $E$. coli and E. sakazakii tested.

TABLE 1. MIC and MBC of LF-related compounds against $E$. coli and E. sakazakii strains

\begin{tabular}{|c|c|c|c|c|c|c|}
\hline & \multicolumn{2}{|c|}{ E. coli } & \multicolumn{4}{|c|}{ E. sakazakii } \\
\hline & 0111 & IID861 & ATCC 12868 & ATCC29004 & ATCC29544 & ATCC51329 \\
\hline \multicolumn{7}{|c|}{$\mathrm{MIC}(\mathrm{mg} / \mathrm{ml})$} \\
\hline LF-hyd & 0.25 & 0.13 & 1 & 0.5 & 0.5 & 0.25 \\
\hline LFcin B & 0.016 & 0.008 & 0.031 & 0.031 & 0.031 & 0.016 \\
\hline \multicolumn{7}{|c|}{$\mathrm{MBC}(\mathrm{mg} / \mathrm{ml})$} \\
\hline Apo-LF & 4 & 1 & 8 & 8 & 4 & 4 \\
\hline Fe-LF & $>8$ & 4 & $>8$ & $>8$ & $>8$ & 4 \\
\hline Cu-LF & 2 & 0.5 & 2 & 4 & 4 & 1 \\
\hline LF-hyd & 0.5 & 0.25 & 1 & 1 & 0.5 & 0.5 \\
\hline LFcin B & 0.016 & 0.008 & 0.031 & 0.031 & 0.031 & 0.016 \\
\hline
\end{tabular}



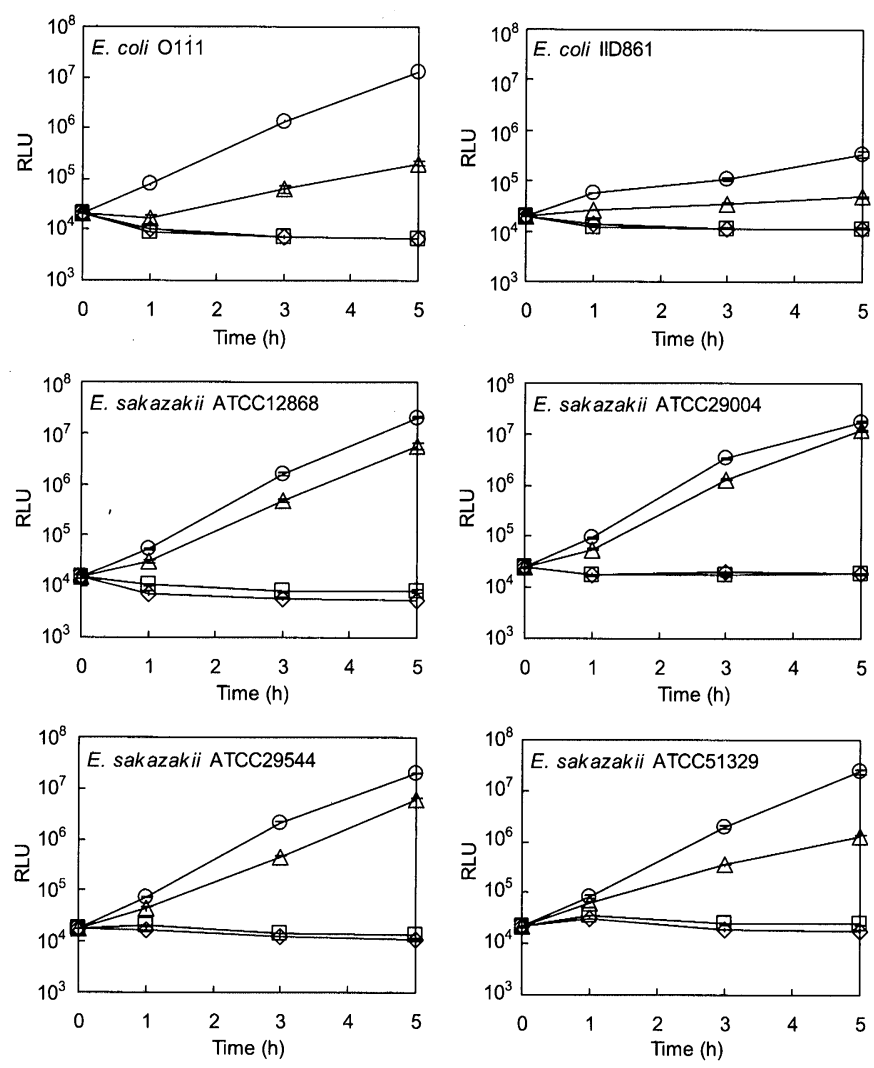

FIG. 1. Effect of apo-LF on the growth of E. coli and E. sakazakii strains. Bacterial growth for $5 \mathrm{~h}$ was monitored by an ATP-based luminescence assay and expressed as relative luminescence units (RLUs) as the mean $\pm S D$ of triplicate cultures. Apo-LF was added at $0(\bigcirc), 0.5(\triangle), 2(\square)$, or $8(\diamond) \mathrm{mg} / \mathrm{ml}$.

Apo-LF at 2 or $8 \mathrm{mg} / \mathrm{ml}$ completely inhibited the growth of all strains.

To test the resistance of LF to temperatures above $70^{\circ} \mathrm{C}$, which is the temperature recommended for the preparation of powdered infant formula by FAO/WHO (2007), we examined the effect of LF being heated at $80^{\circ} \mathrm{C}$ or not heated on the CFU values of $E$. sakazakii grown for $17 \mathrm{~h}$, starting with an inoculum of $10^{6}$ $\mathrm{CFU} / \mathrm{ml}$ (Fig. 2). Non-heated LF at $0.5-4 \mathrm{mg} / \mathrm{ml}$ suppressed the CFU values of $E$. sakazakii in a dosedependent manner. Heated LF at $1-4 \mathrm{mg} / \mathrm{ml}$ suppressed the bacterial CFU values, but it showed no effect at $0.5 \mathrm{mg} / \mathrm{ml}$. Both heated and non-heated LF had a killing effect at $4 \mathrm{mg} / \mathrm{ml}$.

In this study, we examined the antimicrobial effect of bovine LF-related compounds on 4 strains of $E$. sakazakii in comparison with that on 2 strains of $E$. coli, of which the latter 2 strains are already known to be susceptible to bovine LF and LFcin B (Wakabayashi et al., 2003). E. sakazakii as well as E. coli was susceptible to apo-LF, Cu-LF, LF-hyd, and

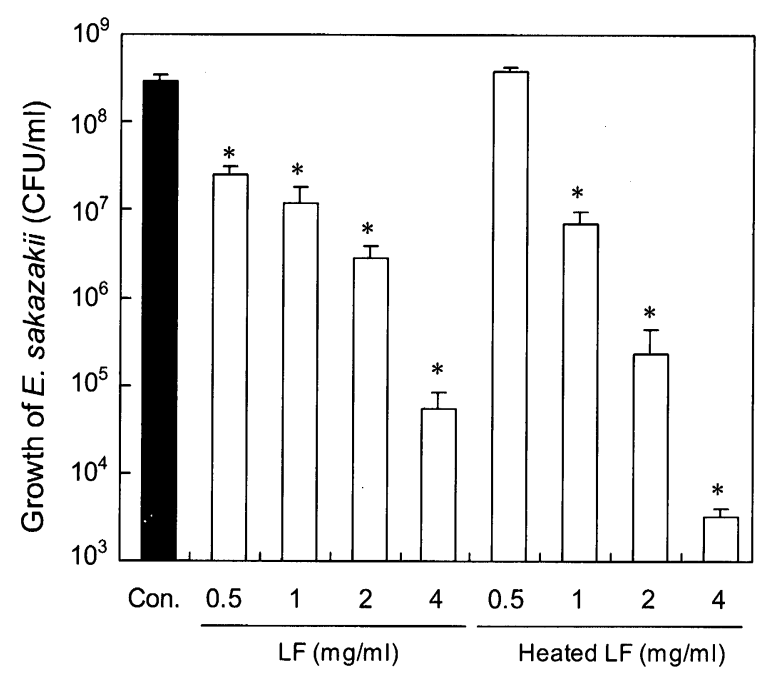

FIG. 2. Effect of heat-treated LF on the growth of $E$. sakazakii. LF was dissolved in water at $80^{\circ} \mathrm{C}$ or room temperature. E. sakazakii ATCC5 1329 at $10^{6} \mathrm{CFU} / \mathrm{ml}$ was incubated in the presence of the heat-treated or non-treated LF at the indicated concentrations. After $17 \mathrm{~h}$ of incubation, CFU values were determined and expressed as the mean $\pm S D$ of triplicate cultures. ${ }^{*} P$ $<0.05$ was as compared with control cells with no added test agent when analyzed by the two-tailed Student $t$ test.

LFcin B. E. sakazakii exhibited a somewhat lower susceptibility to these compounds than E. coli. The susceptibility of E. sakazakii varied among strains, but the inter-strain variation was small (2-4 folds in $\mathrm{MBC}$ or MIC). While apo-LF at $0.5 \mathrm{mg} / \mathrm{ml}$ weakly suppressed the growth of all strains tested during $5 \mathrm{hr}$ of incubation in the ATP-luminescence assay, this compound at 2 or $8 \mathrm{mg} / \mathrm{ml}$ completely inhibited growth. While this method did not allow the detection of bactericidal activity, the MBC of apo-LF was $1-8 \mathrm{mg} / \mathrm{ml}$ (Table 1), indicating that these concentrations of apo-LF had killing effects. This assumption is in accordance with the results of CFU determination in the presence of native LF (Fig. 2).

A higher effectiveness of Cu-LF but not Fe-LF compared to apo-LF was noted in the MBC test. It has been reported that the growth-inhibitory effect of $\mathrm{Cu}$ LF against E. coli and Staphylococcus aureus is more potent than that of apo-LF and Fe-LF (Saito et al., 1996). Cu salt at a concentration corresponding to a Cu content of $8 \mathrm{mg} / \mathrm{ml}$ of Cu-saturated LF $(50 \mu \mathrm{g} /$ $\mathrm{ml}$ of $\mathrm{CuSO}_{4} \cdot 5 \mathrm{H}_{2} \mathrm{O}$ ) did not show any inhibitory activity against $E$. sakazakii in MIC and MBC testing (data not shown), suggesting that $\mathrm{Cu}^{2+}$ ions released from Cu-LF are not responsible for the antimicrobial activity of Cu-LF. It has been reported that the crystal structure of Cu-LF is the same as that of Fe-LF 
(Smith et al., 1992). Therefore, the mechanism responsible for the greater effectiveness of Cu-LF is currently unknown. However, Cu-LF may be a useful compound for the inhibition of pathogenic bacteria, including $E$. sakazakii.

Among the tested agents, antimicrobial peptide LFcin B was the most effective against E. sakazakii as well as against $E$. coli in the MIC and MBC tests. The MIC values of LFcin B against $E$. coli and $E$. sakazakii were the same as the MBC values, being $8-31 \mu \mathrm{g} / \mathrm{ml}(2.5-10 \mu \mathrm{M})$. These MIC values seem to be lower than those of recently reported caseinderived antimicrobial peptides effective against $E$. sakazakii, which had MIC values of $52 \mu \mathrm{g} / \mathrm{ml}$ (50 $\mu \mathrm{M})$ to $213 \mu \mathrm{g} / \mathrm{ml}(220 \mu \mathrm{M})$ against $E$. coli (Hayes et al., 2006).

Bovine LF or LF-hyd containing LFcin B has been used as a supplement to some infant formulas (Wakabayashi et al., 2006). Bovine LF heated at 80 ${ }^{\circ} \mathrm{C}$ showed similar anti-Enterobacter activity to nonheated LF at above $1 \mathrm{mg} / \mathrm{ml}$. This observation suggests that LF in the powdered infant formula may retain its antimicrobial activity to some extent after reconstitution with hot water. In conclusion, bovine LFrelated compounds may have potential usefulness for the prevention of infection by $E$. sakazakii in foods such as infant formula.

\section{REFERENCES}

Ainscough, E.W., Brodie, A.M., and Plowman, J.E. (1979) The chromium, manganese, cobalt and copper complexes of human lactoferrin. Inorganica Chimica Acta, 33, 149-153.

Bellamy, W., Takase, M., Yamauchi, K., Wakabayashi, H., Kawase, K., and Tomita, M. (1992) Identification of the bactericidal domain of lactoferrin. Biochim. Biophys. Acta, 1121, 130-136.

Chierici, R. (2001) Antimicrobial actions of lactoferrin. Adv. Nutr. Res., 10, 247-269.

Drudy, D., Mullane, N.R., Quinn, T., Wall, P.G., and Fanning, S. (2006) Enterobacter sakazakii: an emerging pathogen in powdered infant formula. Clin. Infect. Dis., 42, 9961002.
FAO [Food and Agriculture Organization of the United Nations]/WHO [World Health Organization]. (2007) Safe preparation, storage and handling of powdered infant formula - Guidelines. ISBN 9789241595148.

Hayes, M., Ross, R.P., Fitzgerald, G.F., Hill, C., and Stanton, C. (2006) Casein-derived antimicrobial peptides generated by Lactobacillus acidophilus DPC6026. Appl. Environ. Microbiol., 72, 2260-2264.

Kandhai, M.C., Reij, M.W., Gorris, L.G.M., Guillaume-Gentil, O., and van Schothorst, M. (2004) Occurrence of Enterobacter sakazakii in food production environments and households. Lancet, 363, 39-40.

Lehner, A., and Stephan, R. (2004) Microbiological, epidemiological, and food safety aspects of Enterobacter sakazakii. J. Food Prot., 67, 2850-2857.

Nair, M.K.M., Joy, J., and Venkitanarayanan, K.S. (2004) Inactivation of Enterobacter sakazakii in reconstituted infant formula by monocaprylin. J. Food Prot., 67, 28152819.

Saito, H., Miyakawa, H., Ishibashi, N., Tamura, Y., Hayasawa, H., and Shimamura, S. (1996) Effect of ironfree and metal-bound forms of lactoferrin on the growth of Bifidobacteria, E. coli and S. aureus. Biosci. Microflora, $15,1-7$.

Smith, C.A., Anderson, B.F., Baker, H.M., and Baker, E.N (1992) Metal substitution in transferrins: the crystal structure of human copper-lactoferrin at 2.1-A resolution. Biochemistry, 31, 4527-4533.

Teraguchi, S., Shin, K., Ogata, T., Kingaku, M., Kaino, A., Miyauchi, H., Fukuwatari, Y., and Shimamura, S. (1995) Orally administered bovine lactoferrin inhibits bacterial translocation in mice fed bovine milk. Appl. Environ. Microbiol., 61, 4131-4134.

Tomita, M., Wakabayashi, H., Yamauchi, K., Teraguchi, S., and Hayasawa, H. (2002) Bovine lactoferrin and lactoferricin derived from milk: production and applications. Biochem. Cell Biol., 80, 109-112.

Van Acker, J., de Smet, F., Muyldermans, G., Bougatee, A., Naessens, A., and Lauwers, S. (2001) Outbreak of necrotizing enterocolitis associated with Enterobacter sakazakii in powdered milk formula. J. Clin. Microbiol., 39, 293-297.

Wakabayashi, H., Takase, M., and Tomita, M. (2003) Lactoferricin derived from milk protein lactoferrin. Curr. Pharm. Des. 9, 1277-1287.

Wakabayashi, H., Yamauchi, K., and Takase, M. (2006) Lactoferrin research, technology and applications. Int. Dairy J., 16, 1241-1251. 